\title{
The Phenols of the Genus Agave (Agavaceae)
}

\author{
Norma Almaraz-Abarca ${ }^{*}$ Eli Amanda Delgado-Alvarado, José Antonio Ávila-Reyes, \\ José Natividad Uribe-Soto, Laura Silvia González-Valdez
}

Centro Interdisciplinario de Investigación para el Desarrollo Integral Regional Unidad Durango, Instituto Politécnico Nacional, Durango, Dgo, México.

Email: "noralab@yahoo.com,nalmaraz@ipn.mx

Received April $3^{\text {rd }}, 2013$; revised May $12^{\text {th }}, 2013$; accepted May $28^{\text {th }}, 2013$

Copyright (C) 2013 Norma Almaraz-Abarca et al. This is an open access article distributed under the Creative Commons Attribution License, which permits unrestricted use, distribution, and reproduction in any medium, provided the original work is properly cited.

\begin{abstract}
A review is presented about the studies that have been carried out on the phenolic composition of the species of the genus Agave in order to show which species of the genus has been analyzed, what is the potential of the species of Agave as source of phenolics with important biological activities, and what is the significance of the phenolic profiles as chemotaxonomic markers in the genus. The results of the analysis of a dozen of Agave species reveal an important richness of phenolic compounds, including flavonoids, homoisoflavonoids, and phenolic acids, and a broad diversity of biological activities associated to those compounds, as antioxidant, antibacterial, antifungal, antinematod, and immunomodulatory capabilities. The phenols of Agave also have a major potential as specific chemotaxonomic markers.
\end{abstract}

Keywords: Genus Agave; Phenol Profiles; Homoisoflavanoids; Biological Activity; Chemotaxonomic Markers

\section{Introduction}

Plant kingdom has been a major source of useful substances for the human health [1] and important advances in the knowledge of the chemical composition of a great deal of plant species have been got [2-4]. However, a great deal of plant species waits yet to be the aim of phytochemical studies.

The plant phenols are among the most studied secondary metabolites, their broad distribution in plant kingdom, great chemical diversity [5], and wide spectrum of biological activities [6-8], some with important impact on mammalian biology [9], making them attractive for phytochemical studies. The screening of phenol composition of plant extracts may reveal the diversity, the abundance, and the distribution of those important compounds in the plant kingdom, and as well may facilitate the identification of alternative sources of natural products with biological activities. The exploration of the phenolic compounds accumulated by the vast plant species worldwide and the creation of databases systematizing the information about the distribution, variability, and biological properties of those compounds are among the major issues to advance in the understanding of the use and conservation of plants as source of bene-

${ }^{*}$ Corresponding author. ficial chemical compounds for the human being.

Few species of the genus Agave have been studied for their phenol composition and related biological activities, but the results of the studies before done suggest that an important richness of biologically active phenolics exists in the genus. The relevance and the efforts already made are worthy for systematizing the information in order to facilitate sustainable further studies. That was the aim of the present paper.

\section{Genus Agave}

The genus Agave belongs to the monocotyledonous family Agavaceae. Agave comprises around 166 species $[10,11]$, which naturally grow in Northern and Central America [12], although some species can be found growing as introduced in several countries of Africa [13] and Asia [7], where are used as food, source of fiber, or ornamental. Mexico is the centre of origin of genus Agave [14]. With 125 species growing mainly in the arid and semiarid zones, this is the country with the highest richness of species of Agave [11], 74\% being endemic [14]. According to the type of inflorescence, the genus is split in subgenus Agave and subgenus Littaea [12]. Several taxonomic controversies exist in the specific delimitation in the genus $[12,15]$.

Most species of Agave are predominantly monocarpic 
rosettes reaching the blooming state at the age of around seven to ten years, dying little after. The inflorescences of those species are among the largest ones in the plant kingdom, reaching up to 10 meters above ground. However, some species of the subgenus Littaea are rosettes nonmonocarpic [12].

Due to their chemical composition, the species of Agave provides to the humans of carbohydrate-rich foods [16], mainly rich in fructans [17,18], which are important probiotic compounds [19]. In several regions of Mexico, the carbohydrates of some species, after fermented and distilled, are used to elaborate alcoholic beverages like tequila, mescal and bacanora [20]. The species of this genus synthesize diverse secondary metabolites, which are used in traditional medicine as anticancerigenic, anti- inflamatory, and antiparasitic substances, among others [21].

The species of genus Agave are rich in saponins and these are the secondary metabolites most studied in that genus [22-32]. However, the species of Agave also synthesize an important richness and abundance of phenolic compounds. In the Table 1, a compilation of the Agave species studied for their phenolic composition, phenolic content, and/or the biological activities, related to their phenols, is present.

Flavonoids are among the most ubiquitous phenolic compounds occurring in practically all parts of plants. Many of those compounds have several biological properties with medical implications [33,34]. Flavonoids have been reported to be accumulated in the tissues of

Table 1. Species of Agave studied for their phenols.

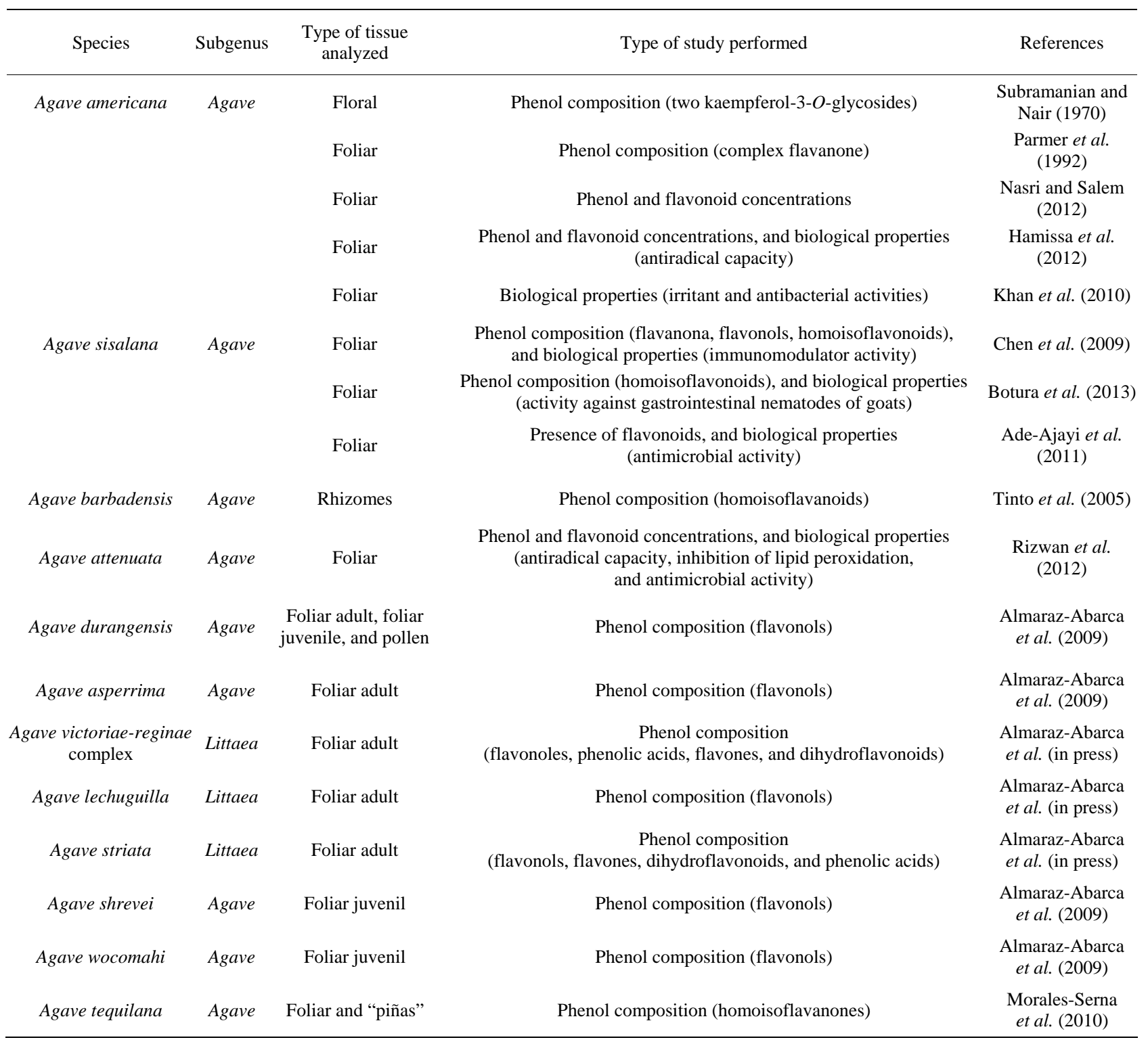


the species of Agave [7,35,36]. The homoisoflavanoids, which are compounds with 16 carbon structures, a chromanone system, and a benzyl group at position 3 [37]; and the phenolic acids have also been reported [38].

\section{Species of Agave Studied for Their Phenol Composition, Contents of Total Phenols and Total Flavonoids, and for Their Biological Activities}

Agave americana $L$. This is one of the first and most studied species of Agave; for this species Subramanian and Nair [35] reported two flavonol glycosides (kaempferol-3-O-glucoside and kaempferol-3-O-rutinoside) present in the flowers, and latter, Parmar et al. [39] reported a complex flavanone (5,7-dihydroxi-6,5'-dimetoxi-3', 4'-metilenedioxiflavanone) in the somatic tissues of that same species. More recently, reports about the phenol, tannin, and flavonoid foliar contents, and the biological properties associated to those contents of A. americana have appeared. Nasri and Salem [40] reported the levels of total phenols and total tannins of leaves of $A$. americana growing in Tunisia; with $7.7 \mathrm{~g} / \mathrm{Kg}$ dry matter of total phenols and $2.5 \mathrm{~g} / \mathrm{Kg}$ dry matter of tannins. The results of Nasri and Salem [40] agreed with those of Hamissa et al. [41], who reported contents of total phenols between 4.49 and $12.30 \mathrm{mg} / \mathrm{g}$ dry weight, and of total flavonoids between 0.96 and $4.90 \mathrm{mg} / \mathrm{g}$ dry weight, depending on different extraction conditions, in the leaves of A. americana. No information about the kinds of phenols accumulated in the leaves of A. americana was provided by Nasri and Salem [40] neither by Hamissa et al. [41], but these last authors reported the important antiradical properties of the foliar phenols of $A$. americana.

Others reports, like that of Khan et al. [42] have been published informing about antibacterial activities of extracts of leaves of Agave americana, attributing those properties, in part, to the homoisoflavonoids previously reported. In the root of A. americana cultivated in India, no flavonoids neither tannins were found by Kadam et al. [43].

Agave barbadensis Trel. This is other species of Agave from which also complex homoisoflavanoids (7-hydroxy-3-(4'-methoxybenzyl)chroman, 7-hydroxy-3-(4'-methoxybenzyl)chroman-4-one, and 5,7-dihydroxy-3-(4'methoxybenzyl)chroman-4-one) have been identified in the rhizomes [28].

Agave sisalana Perrine ex. Engelm. Chen et al. [7] isolated and identified, by semipreparative normal-phase HPLC and NMR, one flavanone (5,7-dihydroxyflavanone), two flavonols (kaempferol-3-rutinoside-4'-glucoside and kaempferol-3-(2 $2^{\mathrm{G}}$-rhamnosylrutinoside)), and seven homoisoflavonoids (7-O-methyleucomol, 3'-desoxysappanone, ( \pm )-3,9-dihydroeucomin, dihydro-bonducellin, 7-hydroxy-3-(4'-hydroxybenzyl)chromone, 5,7dihydroxy-3-(4'-hydroxybenzyl)-4-chromanone, and 5,7dihydroxy-3-(3'-hydroxy-4'-methoxybenzyl)-4 chromanone) from the leaves of Agave sisalana growing in China. None of those compounds was previously reported in $A$. americana and A. barbadensis [28]. Chen et al. [7] reported an important immunomodulatory activity for $( \pm)$ -3,9-dihydroeucomin, dihydro-bonducellin, and for 5,7dihydroxy-3-(4'-hydroxybenzyl)-4-chromanone.

Besides of the immunomodulatory activity of phenolic compounds of A. sisalana, activity against gastrointestinal nematodes of goats, associated to the homoisoflavonoids present in the foliar decortication wastes of plants growing in Brazil, was reported by Botura et al. [6]; the homoisoflavonoids carried out that activity by inhibiting the egg hatch and the larval migration. Ade-Ajayi et al. [44] reported activity against five strains of pathogenic microorganism for the foliar extracts prepared from leaves of A. sisalana growing in Nigeria, in which those authors found qualitative evidences of the presence of flavonoids.

Agave attenuata Salm-Dick. This is other species of the genus Agave, which have recently received attention to investigate its phenol and flavonoid contents and its biological activity. Rizwan et al. [45] reported levels between 10.54 and $39.35 \mathrm{mg} / 100 \mathrm{~g}$ of dry plant matter, and 43 and $304.8 \mathrm{mg} / 100 \mathrm{~g}$ of dry plant matter for the foliar total phenolic and total flavonoid contents, respectively, of $A$. attenuate growing in Pakistan; the variability in the contents depended on the different solvents used for preparing the extracts. Those levels were lower than those reported for the leaves of $A$. americana by Nasri and Salem [40] and Hamissa et al. [41]; however Rizwan et al. [45] reported relevant antiradical activities (from $61.41 \%$ to $73.97 \%$ inhibition of $\mathrm{DPPH}^{*}$ ), potentials of inhibition of lipid peroxidation (from $50.12 \%$ to $70.35 \%$ ), and important antimicrobial properties against nine species of bacteria for the foliar extracts of A. attenuata.

Agave tequilana Weber. This species is the raw material for the manufacturing of tequila, and recently its "piñas" and leaves were studied for their phenol composition by Morales-Serna et al. [37]. These authors reported three homoisoflavanones (5,7-dihydroxy-3-(4'methoxybenzyl)-chroman-4-one, 7-hydroxy-3-(4'-hydroxybenzyl)-chroman-4-one, and 4'-demethyl-3,9-dihy-dropunctatin), identified by NMR, in plants growing in Mexico. The 5,7-dihydroxy-3-(4'-methoxybenzyl)-chroman-4-one was found also in A. barbadensis [28]. The three homoisoflavanones of $A$. tequilana were different to those reported by Chen et al. [7] for A. sisalana. 


\section{Species of Agave Studied by the Inter and Intraspecific Variability in Their Phenolic Profiles}

Agave durangensis Gentry. None of the reports mentioned above had as aim to evaluate the variability inter or intraspecific of the phenol profiles, actually few reports with that aim have appeared. One of them is that of the Almaraz-Abarca et al. [36], in which, by using HPLCDAD, 23 flavonoids were reported in the adult foliar tissues of Agave durangensis, all being flavonol glycosides, the most being derivatives of kaempferol, but one quercetin glycoside (quercetin-3-O-arabinoside) was also found. The individual profiles varied from three to nine compounds in one natural population of this species, and from three to four in another one. The level of variation in the foliar phenol patterns allowed clearly discerning between two natural populations, and inside one of the populations, three chemotypes were revealed.

Agave asperrima Jacobi. This species was revealed to have simple and little variable foliar phenol profiles. Almaraz-Abarca et al. [36] reported three kaempferol glycosides as unique components of the adult foliar tissues of a natural population of $A$. asperrima. The profiles of $A$. asperrima were different from those of $A$. durangensis, in such a way that a principal coordinates analysis (PCO) clearly separated the samples of each those two both species.

Agave victoriae-reginae T. Moore complex. In the Agave victoriae-reginae complex, recently proposed as a complex instead of a single species, formed by A. pintilla, A. nickelsii, A. victoriae-reginae subspecies victoriaereginae, and A. victoriae-reginae subspecies swobodae [46], 11 flavonols, majorly derivatives of quercetine-3$O$-glycosides, but also one kaempferol-3-O-glycoside, one isorhamnetin derivative, and the kaempferol aglycone; besides of five flavones, nine dihydroflavonoids, and 15 phenolic acids were found [38]. Agave pintilla was distinguished from the others taxa of the A. victoriaereginae complex by possessing four unique compounds. But the foliar phenol profiles did not allowed distinguishing between A. victoriae-reginae s. str. (A. victoriae-reginae subspecies victoriae-reginae and $A$. victoriae-reginae subspecies swobodae) and $A$. nickelsiae, as found by Martínez-Palacios et al. [47] using allozymes.

Agave lechuguilla Torr. and A. striata Zucc. The intra and interspecific variability of the phenolic composition of the foliar tissues of A. lechuguilla and A. striata were also determined by Almaraz-Abarca et al. [38], those authors reported 24 phenols forming the profiles of each A. striata and A. lechuguilla, the most being different in each species. Seven flavonols (majorly quercetin-3-Oglycosides, but also one kaempferol-3-O-glycoside); besides of one flavone; seven dihydroflavonoids; and five phenolic acids were reported for A. lechuguilla. For A. striata, 14 flavonols (the most being also quercetin3-O-glycosides, but also one kaempferol-3-O-glycoside, and one herbacetin-3-O-glycoside), besides one flavone; six dihydroflavonoids; and three phenolic acids were found. The intrapopulation profiles varied between 12 and 20, and between 11 and 19 phenolic compounds for A. lechuguilla and A. striata, respectively.

The phenolic acids have been reported only in the foliar tissues of Agave victoriae-reginae complex, A. lechuguilla, and $A$. striata, all those three taxa belonging to the subgenus Littaea. The phenolic acids provide the precursors for lignin, tannin, and flavonoid biosynthesis $[48,49]$. Some authors have mentioned than the species of Agave synthesize neither relevant amounts of foliar lignin nor tannins [50], others have not found tannins in the roots [43], and other more have reported qualitative evidence of the presence of tannins in leaves [44]. The functions of phenolic acids in plant species that apparently do not accumulate relevant amounts of foliar lignin either tannins, like the species of Agave, may be related to some or all the other several roles reported for these phenols, like the protection against herbivores and pathogens, the action as cementing material joining phenolic polymers to polysaccharides of cell walls [51], the participation in the regulation of cell growth and division [52], the inhibition of ion intake by a generalized increase in membrane permeability to inorganic ions as a mode of action of allelopathic compounds [53], and the function as antioxidants $[54,55]$.

\section{Species of Agave Studied by the Effects That the Age of Development and Environmental Conditions Have on the Phenolic Profiles}

Agave durangensis, A. shrevei Gentry, and A. wocomahi Gentry. The accumulation of flavonoids, and in general of any phenolic compound, in the different plant species can be strongly affected by environmental conditions like UV radiation and water supply, causing mainly quantitative variations while the patterns of accumulated phenolics may remained stable [56]. The developmental conditions, like the maturation process also have effects in the accumulations of phenols [57]; this was corroborated for Agave durangensis by Almaraz-Abarca et al. [36], who reported 23 different kaempferol-3-O-glycosides accumulated in the foliar tissues of juvenile individuals, most of those being compounds different from the kaempferol glycosides found in the foliar tissues of adult plants of the same species. Intraspecific variability was also observed, indicated by the variation in the individual profiles, which were formed by three to 11 flavonols.

Almaraz-Abarca et al. [36] also reported the foliar 
phenol composition of juvenile individuals of Agave shrevei subsp. shrevei, A. shrevei subsp. matapensis, and A. wocomahi; the profiles of the two subspecies were formed by three kaempferol-3-O-glycosides (one shared by the two subspecies), and the profiles of $A$. wocomahi included four kaempferol-3-O-glycosides, one being exclusive for this last species, one shared with the two subspecies of $A$. shrevei and with A. durangensis, and two shared only with $A$. durangensis.

\section{Species of Agave Studied by Their Pollen Phenol Composition}

Pollen is considered as an important source of flavonol glycosides and phenolic acids $[55,58]$. The species of Agave produce high quantities of pollen and nectar. To our knowledge, Agave durangensis is the only species of Agave which has been analyzed for its pollen phenolic composition. Other studies have been done on the entire flowers [35]. Almaraz-Abarca et al. [36], using a gradient method of HPLC-DAD reported profiles formed by 13 flavonols, being 12 kaempferol glycosides and one myricetin glycoside (myricetin-3-O-rhamnoside). The pollen phenol composition and its participation in providing some biological activity to extracts of flowers of the species of Agave must be subjected to further analysis. Some results have been reported informing about the antifungal activity of flower extracts of A. asperrima and A. striata, with levels of minimum inhibitory concentrations (MIC) of 0.2 to $2.0 \mathrm{mg} / \mathrm{mL}$, but neither the characterization of the active compounds nor the type of tissue (tepals, pollen, or pistils) accumulating the active substances were assessed [59].

\section{The Relevance of Phenol Profiles as Taxonomic Markers in the Genus Agave}

Flavonoid profiles have been reported as worthy chemical markers with a species-specific tendency [60-63]. In spite of the important taxonomic controversies about the delimitation of many species of Agave [12,15], efforts focused in determining the taxonomic significance of the phenol profiles in this genus have been scarce. The study of Almaraz-Abarca et al., [36], focused on the taxonomic significance of the phenol profiles in Agave, pointed out that foliar flavonoid profiles are valuable markers to discriminate among Agave durangensis, A. asperrima, A. wocomahi, A. shrevei subsp. shrevei, and A. shrevei subsp. matapensis; and the study of Almaraz-Abarca et al. [38] showed that $A$. pintilla, member of the $A$. victoriae-reginae complex, displayed a such a different foliar phenol composition that its separation as an independent species, proposed by González-Elizondo et al. [46], was supported by those chemotaxonomic markers. Intrapopulation variability was detected in both of those studies [36,38]; however, type profiles with a speciesspecific tendency allowed discriminating between species.

According to the results of the papers reviewed, the species of Agave belonging to the subgenus Littaea could accumulate classes of phenols, which are different than those accumulated by the species of the subgenus Agave, but further research is needed to conclude.

\section{Concluding Remarks}

The investigation of the phenol composition and the biological activities of the species of genus Agave have been a matter of intensive studies in the last few years. The results of that investigation have revealed an important richness, diversity, and abundance of phenolic compounds in the floral and foliar tissues of a dozen of species of Agave, besides have shown the important and diverse biological activities associated to those compositions, and the significance of the phenolic profiles as specific chemotaxonomic markers in the genus. Those results indicate that the species of Agave is a worthily source of flavonoids, homoisoflavonoids, and phenolic acids with importance as antioxidants, antibacterial and antifungal compounds, immunomodulators substances, and antinematod components, which could be regarded as nutraceutical product for application in food and beverages, and as substances with potential to develop medicinal compounds for humans and animals. Besides, those results indicate that the species-specific tendency of the phenolic patterns gives them important chemotaxonomic markers which could contribute to solve the present taxonomic controversies in the specific delimitation in the genus Agave. The results of the several papers revised in the present study should stimulate the performance of more analysis focused on the exploration of the phenolic compositions of the others species of Agave, the biological activities associated, and the effects that different biotic and abiotic factors, and the age of development have on the patterns of synthesis and accumulation.

\section{Acknowledgements}

The authors appreciate the help of the Comisión de Fomento a las Actividades Académicas del Instituto Politécnico Nacional (COFAA IPN) for the stimuli for research.

\section{REFERENCES}

[1] A. P. Da Cunha and O. R. Roque, "A Farmacognosia nos Estudios Farmacéuticos,” In: A. P. Da Cunha, Ed., Farmacognosia e Fitoquímica, Fundação Calouste Gulbenkain, Lisboa, 2005, pp. 3-15.

[2] J. C. M. Barreira, I. C. F. R. Ferreira, M. B. P. P. Oliveira and J. A. Pereira, "Antioxidant Activities of the Extracts 
from Chesnut Flower, Leaf Skins and Fruit,” Food Chemistry, Vol. 107, No. 3, 2008, pp. 1106-1113. doi:10.1016/j.foodchem.2007.09.030

[3] A. Champagne, G. Hilbert, L. Legendre and V. Lebot, "Diversity of Anthocyanins and Other Phenolic Compounds Among Tropical Root Crops from Vanuatu, South Pacific," Journal of Food Composition and Analysis, Vol. 24, No. 3, 2011, pp. 315-325. doi:10.1016/j.jfca.2010.12.004

[4] Z. Tai, L. Cai, L. Dai, L. Dong, M. Wang, Y. Yang, Q. Cao and Z. Ding, "Antioxidant Activity and Chemical Constituents of Edible Flower of Sophora viccifolia," Food Chemistry, Vol. 126, No. 4, 2011, pp. 1648-1654. doi:10.1016/j.foodchem.2010.12.048

[5] M. Jai, “C-Glycosylflavonoids,” In: J. B. Harborne, Ed., The Flavonoids Advances in Research since 1986, Chapman \& Hall, London, 1994, pp. 57-93.

[6] M. B. Botura, J. D. G. dos Santos, G. D. da Silva, H. G. de Lima, J. V. A. de Oliveira, M. A. O. de Almeida, M. J. M. Atatinha and A. Blanco, "In Vitro Ovicidal and Larvacidal Activity of Agave sisalana Perr (sisal) on Gastrointestinal Nematodes of Goats,” Veterinary Parasitology, Vol. 192, No. 1-3, 2013, pp. 211-217. doi:10.1016/j.vetpar.2012.10.012

[7] P. Y. Chen, Y. C. Kuo, C. H. Chen, Y. H. Kuo and C. K. Lee, "Isolation and Immunomodulatory Effect of Homoisoflavones and Flavones from Agave sisalana Perrine ex Engelm,” Molecules, Vol. 14, No. 5, 2009, pp. 17891795. doi:10.3390/molecules14051789

[8] M. M. Win, A. Abdul-Hamid, B. S. Baharin, F. Anwar, M. C. Sabu and M. S. Pak-Dek, "Phenolic Compounds and Antioxidant Activity of Peanut's Skin, Hull, Raw Kernel and Roated Kernel Flour," Pakistan Journal of Botany, Vol. 43, No. 3, 2011, pp. 1635-1642.

[9] E. Jr. Middleton and C. Kandaswami, "The Impact of Plant Flavonoids on Mammalian Biology: Implications for Immunity, Inflammation, and Cancer,” In: J. B. Harborne, Ed., The Flavonoids Advances in Research Since 1986, Chapman \& Hall, London, 1994, pp. 619-652.

[10] V. S. Good-Ávila, V. Souza, S. B. Gaut and E. L. Eguiarte, "Timing and Rate of Speciation in Agave (Agavaceae)," Proceedings of the National Academy of Science USA, Vol. 103, No. 24, 2006, pp. 9124-9129. doi:10.1073/pnas.0603312103

[11] M. Rocha, S. V. Good-Ávila, F. Molina-Freaner, H. T. Arita, A. Castillo, A. García-Mendoza, A. Silva-Montellano, B. S. Gaut, V. Souza and L. E. Eguiarte, "Pollination Biology and Adaptive Radiation of Agavaceae, with Special Emphasis on the Genus Agave," Aliso, Vol. 22, 2006, pp. 329-344.

[12] H. S. Gentry, "Agaves of Continental North America," The University of Arizona Press, Tucson, 1982.

[13] P. E. Zwane, M. T. Masarirambi, N. T. Nagagula, A. M. Dlamini and E. Bhebhe, "Exploitation of Agave americana L. Plant for Food Security in Swaziland," American Journal of Food and Nutrition, Vol. 1, No. 2, 2011, pp. 82-88. doi:10.5251/abjna.2011.1.2.82.88

[14] A. García-Mendoza, "Riqueza y Endemismos de la Familia Agavacea en México,” In: E. Linares, P. Dávila, F. Chiang,
R. Bye and T. Elias, Eds., Conservación de Plantas en Peligro de Extinción: Diferentes Enfoques, UNAM, México, D. F., 1995, pp. 51-75.

[15] M. González-Elizondo, R. Galván-Villanueva, I. L. LópezEnríquez, L. Reséndiz-Rojas and M. S. González-Elizondo, “Agaves. Magueyes, Lechuguillas y Noas del Estado de Durango y sus Alrededores," IPN-CONABIO-COCYTED, México, 2009.

[16] A. Sotelo, S. López-García and F. Basurto-Peña, “Content of Nutrient and Antinutrient in Edible Flowers of Wild Plants in Mexico," Plant Foods for Human Nutrition, Vol. 62, No. 3, 2007, pp. 133-138. doi:10.1007/s11130-007-0053-9

[17] N. A. Mancilla-Margalli and M. G. López, "Water-Soluble Carbohydates and Fructan Structure Patterns from Agave and Dasylirion Species," Journal of Agricultural and Food Chemistry, Vol. 54, No. 20, 2006, pp. 78327839. doi:10.1021/jf060354v

[18] C. Michel-Cuello, B. I. Juárez-Flores, J. R. AguirreRivera and J. M. Pinos-Rodríguez, "Quantitative Characterization of Nonstructural Carbohydrates of Mezcal Agave (Agave salmiana Otto ex Salm-Dick),” Journal of Agricultural and Food Chemistry, Vol. 56, No. 14, 2008, pp. 5753-5757. doi:10.1021/jf800158p

[19] L. Madrigal and E. Sangronis, "La Inulina y Derivados como Ingredientes Claves en Alimentos Funcionales," Archivos Latinoamericanos de Nutrición, Vol. 57, No. 4, 2007, pp. 387-396.

[20] J. A. Ávila-Reyes, N. Almaraz-Abarca, E. A. DelgadoAlvarado, L. S. González-Valdez, G. Valencia-del Toro and E. Durán-Páramo, "Phenol Profile and Antioxidant Capacity of Mescal Aged in Oak Wood Barrels,” Food Research International, Vol. 43, No. 1, 2010, pp. 296300. doi:10.1016/j.foodres.2009.10.002

[21] L. Santos-Zea, A. M. Leal-Diaz, E. Cortes-Ceballos and A. J. Gutiérrez-Uribe, "Agave (Agave spp.) and Its Traditional Products as a Source of Bioactive Compounds," Current Bioactive Compounds, Vol. 8, No. 3, 2012, pp. 218-231. doi:10.2174/157340712802762410

[22] M. A. Morales, "Steroidal Sapogenins from Agave cocui," Phytochemistry, Vol. 11, No. 3, 1972, pp. 11911192. doi:10.1016/S0031-9422(00)88496-4

[23] V. A. Bodeiko and P. K. Kintya, "Steroid Saponins. VIII. The Structure of Agave Saponins C' and D from the Leaves of Agave Americana," Chemistry of Natural Compounds, Vol. 11, No. 6, 1975, pp. 775-777. doi:10.1007/BF00568468

[24] B. Wilkomirski, V. A. Bobeyko and P. K. Kintia, "New Steroidal Saponins of Agave Americana," Phytochemistry, Vol. 14, No. 12, 1975, pp. 2657-2659. doi:10.1016/0031-9422(75)85245-9

[25] G. Blunden, Y. Yi and K. Jewer, "Steroidal Sapogenins from Leaves of Agaveae Species,” Phytochemistry, Vol. 17, No. 11, 1978, pp. 1923-1925. doi:10.1016/S0031-9422(00)88734-8

[26] G. Pant, O. P. Sati, K. Miyahara and T. Kawasaki, "Search for Molluscicidal Agents Saponins from Agave cantala Leaves,” Pharmaceutical Biology, Vol. 25, No. 1, 1987, pp. 35-38. doi:10.3109/13880208709060908 
[27] G. C. Uniyal, P. K. Agrawal, O. P. Sati and R. S. Thaker, "Agaveside C, a Steroidal Glycoside from Agave cantala," Phytochemistry Vol. 30, No. 4, 1991, pp. 13361339. doi:10.1016/S0031-9422(00)95232-4

[28] W. F. Tinto, J. L. Simmons-Boyce, S. McLean and W. F. Reynolds, "Constituents of Agave americana and Agave barbadensis,” Fitoterapia, Vol. 76, No. 6, 2005, pp. 594597. doi:10.1016/j.fitote.2005.04.013

[29] G. J. Orestes, A. Meneses, A. M. Simonet, F. A. Macías, C. Nogueiras, A. Gomez and J. A. Escario, "Saponinas Esteroidales de la Planta Agave brittoniana (Agavaceae) con Actividad Contra el Parásito Trichomona vaginalis,” Revista de Biología Tropical, Vol. 56, No. 4, 2008, pp. 1645-1652.

[30] A. Yokosuka, M. Jitsuno, S. Yui, M. Yamazadi and Y. Mimaki, "Steroidal Glycosides from Agave utahensis and their Cytotoxic Activity,” Journal of Natural Products, Vol. 72, No. 8, 2009, pp. 1399-1404. doi:10.1021/np900168d

[31] J. Eskander, C. Lavaud and D. Harakat, "Steroidal Saponins from the Leaves of Agave macroacantha," Fitoterapia, Vol. 81, No. 5, 2010, pp. 371-374. doi:10.1016/j.fitote.2009.11.002

[32] M. Debnath, M. Pandey, R. Sharma, G. S. Thakur and P. Lal, "Biotechnological Intervention of Agave sisalana: A Unique Fiber Yielding Plant with Medicinal Property," Journal of Medicinal Plants Research, Vol. 4, No. 3, 2010, pp. 177-187.

[33] X. Mouren, P. Caillard and F. Schwartz, "Study of the Antiischemic Action of EGb 761 in the Treatment of Peripheral Artherial Occlusive Disease by TcPo2 Determination,” Angiology, Vol. 45, No. 6, 1994, pp. 413-417. doi:10.1177/000331979404500601

[34] Q. Zhang and H. Cui, "Simultaneus Determination of Quercetin, Kaempferol, and Isorrhamnetin in Phytopharmaceuticals of Hippophae rhamnoides L. by High-Performance Liquid Chromatography with Chemiluminescence Detection,” Journal of Separation Science, Vol. 28, No. 11, 2005, pp. 1171-1178. doi:10.1002/jssc. 200500055

[35] S. S. Subramanian and A. G. R. Nair, "Chlorogenein and Kaempferol Glycosides from the Flowers of Agave amaricana,” Phytochemistry, Vol. 9, No. 12, 1970, p. 2582. doi:10.1016/S0031-9422(00)85782-9

[36] N. Almaraz-Abarca, E. A. Delgado-Alvarado, V. Hernández-Vargas, M. Ortega-Chávez, G. Orea-Lara, A. Cifuentes-Díaz de León, J. A. Ávila-Reyes and R. MuñizMartínez, "Profiling of Phenolic Compounds of Somatic and Reproductive Tissues of Agave durangensis Gentry (Agavaceae)," American Journal of Applied Sciences, Vol. 6, No. 6, 2009, pp. 1076-1085. doi:10.3844/ajassp.2009.1076.1085

[37] J. A. Morales-Serna, A. Jiménez, R. Estrada-Reyes, C. Márquez, J. Cárdenas and M. Salmón, "Homoisoflavanones from Agave tequilana Weber,” Molecules, Vol. 15, No. 5, 2010, pp. 3295-3301. doi:10.3390/molecules15053295

[38] N. Almaraz-Abarca, M. S. González-Elizondo, M. G. Campos, Z. E. Ávila-Sevilla, E. A. Delgado-Alvarado and
J. A. Ávila-Reyes, "Variability of the Foliar Phenol Profiles of the Agave victoriae-reginae Complex (Agavaceae)," Botanical Science, 2013, in press.

[39] V. S. Parmar, H. N. Jha, A. K. Gupta and A. K. Prasad, “Agamanona, a Flavanona from Agave Americana," Phytochemistry, Vol. 31, No. 7, 1992, pp. 2567-2568. doi:10.1016/0031-9422(92)83333-T

[40] S. Nasri and H. B. Salem, "Effect of Oral Administration of Agave americana or Quillaja saponaria Extracts on Digestion and Growth of Barbarine Female Lamb," Livestock Sciences, Vol. 147, No. 1-3, 2012, pp. 59-65. doi:10.1016/j.livsci.2012.04.001

[41] A. M. B. Hamissa, M. Seffen, B. Aliakbarian, A. A. Casazza, P. Perego and A. Converti, "Phenolics Extraction from Agave americana (L.) Leaves Using High-Temperature, High-Pressure Reactor,” Food and Bioproducts Processing, Vol. 90, No. 1, 2012, pp. 17-21. doi:10.1016/j.fbp.2010.11.008

[42] M. T. J. Khan, K. Ahmad, M. N. Alvi, N. U. Amin, B. Mansoor, M. A. Saeed, F. Z. Khan and M. Jamshaid, "Antibacterial and Irritant Activities of Organic Solvent Extracts of Agave americana Linn., Albizzia lebbek Benth., Achryranthes aspera Linn., and Abutilon indicum Linn.-A Preliminary Investigation,” Pakistan Journal of Zoology, Vol. 42, No. 1, 2010, pp. 93-97.

[43] P. V. Kadam, K. N. Yadav, R. S. Deoda, N. S. Narappanawar, R. S. Shivatare and M. J. Patel, "Pharmacognostic and Phytochemical Studies on Roots of Agave americana (Agavaceae)," International Journal of Pharmacognosy and Phytochemical Research, Vol. 4, No. 3, 2012, pp. 92-96.

[44] A. F. Ade-Ajayi, C. Hammuel, C. Ezeayanaso, E. E. Ogabiela, U. U. Udiba, B. Anyim and O. Olabanji, "Preliminary Phytochemical and Antimicrobial Screning of Agave sisalana Perrine Juice (Waste)," Journal of Environmental Chemistry and Ecotoxicology, Vol. 3, No. 7, 2011, pp. 180-183.

[45] K. Rizwan, M. Zubair, N. Rasool, M. Riaz, M. Zia-UlHaq and V. de Feo, "Phytochemical and Biological Studies of Agave attenuata," International Journal of Molecular Sciences, Vol. 13, No. 5, 2012, pp. 6440-6451. doi:10.3390/ijms13056440

[46] M. S. González-Elizondo, M. González-Elizondo, I. L. López-Enriquez, L. Reséndiz-Rojas, J. A. Tena-Flores and F. I. Retana-Rentería, "El Complejo Agave victoriaereginae (Agavaceae),” Acta Botanica Mexicana, Vol. 95, 2011, pp. 65-94.

[47] A. Martínez-Palacios, L. E. Eguiarte and G. R. Furnier, "Genetic Diversity of the Endangered Endemic Agave victoriae-reginae (Agavaceae) in the Chihuahuan Desert,” American Journal of Botany, Vol. 86, No. 8, 1999, pp. 1093-1098. doi:10.2307/2656971

[48] G. Hrazdina, "Biosynthesis of Flavonoids,” In: R. W. Hemingway and P. E. Laks, Eds., Plant Polyphenols, Plenum Press, New York. 1992, pp. 61-72. doi:10.1007/978-1-4615-3476-1_4

[49] W. Heller and G. Forkmann, "Biosynthesis of Flavonoids,” In: J. B. Harborne, Ed., The Flavonoids Advances in Research since 1986, Chapman \& Hall, London, 1994, 
pp. 499-535.

[50] D. S. Seigler, "Plant Secondary Metabolism,” Kluwer Academic Publishers, Massachusetts, 2002.

[51] G. Wallace and S. C. Fry, "Phenolic Compounds of the Plant Cell," International Review of Cytology, Vol. 151, 1994, pp. 229-267. doi:10.1016/S0074-7696(08)62634-0

[52] A. N. Binns, R. H. Chen, H. N. Wood and D. G. Lynn, “Cell Division Promoting Activity of Naturally Occurring Dehydrodiconiferyl Glucosides: Do Cell Wall Components Control Cell Division?” Proceedings of the National Academy of Sciences of the United States of America, Vol. 84, No. 4, 1987, pp. 980-984. doi:10.1073/pnas.84.4.980

[53] A. D. M. Glass and J. Dunlop, "Influence of Phenolic Acids on Ion Uptake,” Plant Physiology, Vol. 54, No. 6, 1974, pp. 855-858. doi:10.1104/pp.54.6.855

[54] C. A. Rice-Evans, N. J. Miller and G. Papanga, “Antioxidant Properties of Phenolic Compounds," Trends in Plant Science, Vol. 2, No. 4, 1997, pp. 152-159. doi:10.1016/S1360-1385(97)01018-2

[55] N. Almaraz-Abarca, M. G. Campos, J. A. Ávila-Reyes, N. Naranjo-Jiménez, J. Herrera-Corral and L. S. GonzálezValdez, “Antioxidant Activity of Polyphenolic Extract of Monofloral Honeybee-Collected Pollen from Mesquite (Prosopis juliflora, Leguminosae)," Journal of Food Composition and Analysis, Vol. 20, No. 2, 2007, pp. 119124. doi:10.1016/j.jfca.2006.08.001

[56] M. Veit, C. Beckert, C. Höhne, K. Bauer and H. Geiger, "Iterspecific and Intraspecific Variation of Phenolics in the Genus Equisetum Subgenus Equisetum," Phytochemistry, Vol. 38, No. 4, 1995, pp. 881-891. doi:10.1016/0031-9422(94)00658-G

[57] M. Fu, Z. He, Y. Zhao, J. Yang and L. Mao, “Antioxidant Properties and Involved Compounds of Daylily Flowers in Relation to Maturity,” Food Chemistry, Vol. 114, No. 4, 2009, pp. 1192-1197. doi:10.1016/j.foodchem.2008.10.072

[58] R. Wierman and K. Vietth, “Outer Pollen Wall, an Important Accumulation Site for Flavonoids," Protoplasma, Vol. 118, No. 3, 1983, pp. 230-233. doi:10.1007/BF01281807

[59] E. Sánchez, N. Heredia and S. García, "Inhibition of Growth and Mycotoxin Production of Aspergillus flavus and Aspergillus parasiticus by Extracts of Agave species,” International Journal of Food Microbiology, Vol. 98, No. 3, 2005, pp. 271-279. doi:10.1016/j.ijfoodmicro.2004.07.009

[60] M. G. Campos, “Caracterização do Pólen Apícola pelo seu Perfil em Compostos Fenólicos e Pesquisa de Algumas Actividades Biológicas,” Ph.D. Thesis, Coimbra University, Coimbra, 1997.

[61] J. Fiasson, L. K. Gluchoff-Fiasson and G. Dahlgren, "Flavonoid Patterns in European Ranunculus L. Subgenus Batrachium (Ranunculaceae)," Biochemical Systematics and Ecology, Vol. 25, No. 4, 1997, pp. 327-333. doi:10.1016/S0305-1978(97)00021-5

[62] N. Almaraz-Abarca, M. G. Campos, J. A. Ávila-Reyes, N. Naranjo-Jiménez, J. Herrera-Corral and L. S. GonzálezValdez, "Variability of Antioxidant Activity Among Honeybee-Collected Pollen of Different Botanical Origin,” Interciencia, Vol. 29, No. 10, 2004, pp. 574-578.

[63] N. Almaraz-Abarca, M. S. González-Elizondo, J. A. Tena-Flores, J. A. Ávila-Reyes, J. Herrera-Corral and N. Naranjo-Jiménez, "Foliar Flavonoids Distinguish Pinus leiophylla and Pinus chihuahuana (Coniferales: Pinaceae)," Proceedings of the Biological Society of Washington, Vol. 119, No. 3, 2006, pp. 426-436. doi:10.2988/0006-324X(2006)119[426:FFDPLA]2.0.CO;2 